\title{
REVIEW
}

\section{Tibolone and breast cancer}

\author{
C Tamer Erel, Levent M Senturk, Semih Kaleli
}

Postgrad Med J 2006;82:658-662. doi: 10.1136/pgmi.2005.037184

Tibolone is a relatively new drug for postmenopausal women, which is structurally related to 19-nortestosterone derivatives and exhibits weak oestrogenic, progestogenic and androgenic activities. The effect of tibolone on breast tissue is still obscure. In vitro studies have shown conflicting results regarding the effects of tibolone on breast cells. On the other hand, although epidemiological studies show an increase in the risk of breast cancer among women treated with tibolone, accumulation of data obtained from radiological studies presents promising results. However, the safety of tibolone with regard to breast tissue needs to be investigated further, especially through well-designed, large-scale, randomised-controlled trials.

See end of article for authors' affiliations

.....................

Correspondence to: C T Erel, Department of Obstetrics and Gynecology, Division of Reproductive Endocrinology Cerrahpasa School of Medicine, Istanbul University, Istanbul 81070, Turkey; tamererel@superonline. com

Received 11 May 2005 Accepted 30 January 2006

Accepted 30 Janvary 2006
$\mathrm{T}$ ibolone is the first of a class of compounds known as the selective tissue oestrogenic activity regulators. It is structurally related to 19-nortestosterone derivatives and exhibits weak oestrogenic, progestogenic and androgenic activities. Tibolone itself has no biological activity. The diverse hormonal effects of tibolone result from the action of several key metabolites on various tissues. Tibolone is primarily metabolised into $\delta 4,3 \beta$-hydroxy and $3 \alpha$-hydroxy isomers. These isomers have different binding affinities for oestrogen, progesterone and androgen receptors $^{1}$. The $3 \alpha$-hydroxy and $3 \beta$-hydroxy metabolites bind solely to the oestrogen receptor, whereas the $\delta 4$ isomer has affinity for the progesterone and androgen receptors, but not for the oestrogen receptor.

The concentrations of tibolone metabolites and the metabolic regulation of hormonal activities vary depending on tissue type ${ }^{2-4}$ (fig 1). Tibolone has oestrogenic effects on bone and vaginal tissue. In endometrial tissue the $\delta 4$ isomer functions as a progestogen, whereas in the brain and liver it has androgenic effects. In breast tissue, the main action of tibolone is the strong inhibition of the enzyme activity regulating intramammary oestradiol metabolism.

Tibolone given orally is rapidly absorbed, appearing in the plasma within $30 \mathrm{~min}$ and peaking in $4 \mathrm{~h}$. It is metabolised mainly in the liver and is excreted in the urine and faeces. The elimination half-life is approximately $45 \mathrm{~h}^{5}$

Tibolone treatment is accepted as a hormone replacement therapy (HRT) for postmenopausal women. Tibolone provides relief of vasomotor symptoms and prevention of bone loss without evidence that it stimulates the endometrium in postmenopausal women. It does not seem to stimulate breast tissue.
In this review, we have summarised the effects of tibolone on breast tissue by analysing the data from in vitro cell culture studies, animal studies, and radiological, histopathological and epidemiological studies in humans.

\section{IN VITRO HUMAN STUDIES}

Most breast cancers are hormone dependent. Oestradiol has an important role in the genesis and evolution of breast cancer, and the metabolic pathways of oestradiol in the breast tissue determine its local tissue concentration. Human breast tissue (normal or cancerous) contains all the enzymes for the activation or inactivation of oestradiol: sulphatase, $17 \beta$-hydroxysteroid dehydrogenase, aromatase and sulphotransferases. Aromatase converts androgens into oestrogens, and $17 \beta$-hydroxysteroid dehydrogenase regulates the conversion of oestrone to oestradiol or vice versa. Sulphotransferases convert oestrogens into biologically inactive oestrogen sulphates, and sulphatase transforms oestrogen sulphates into bioactive unconjugated oestradiol. In breast tissue, the sulphatase pathway has a 100-500 times higher activity in producing oestrogens than the aromatase pathway ${ }^{6}$ (fig 2).

MCF-7 and T-47D cancer cell lines or normal mammary glandular cell lines are usually used for in vitro studies. Tibolone and its $\delta 4$ metabolites inhibit the synthesis of oestradiol by blocking sulphatase and 17 $\beta$-hydroxysteroid dehydrogenase activities in MCF-7 and T-47D cell lines, suggesting a potential protective effect against the development of breast cancer $^{7}$ (figs 1 and 2). $3 \alpha$-Hydroxy and $\delta 4$ isomers of tibolone also provoke a dual effect on sulphotransferase activity: the effect is stimulatory at low doses, but an inhibition of this activity is observed at higher doses in MCF-7 and T-47D breast cancer cells. Notably, the $3 \alpha$-hydroxy derivative is the most potent compound in terms of the stimulatory effect on sulphotransferase. ${ }^{9}$

Tibolone is an antiproliferative and proapoptotic drug that induces differentiation of normal breast cells. It also has a proapoptotic effect on breast cancer cell lines. ${ }^{10}$ More recently, Mirkin et $a l^{11}$ have suggested that tibolone and tibolone hydroxy-metabolites have no effect on vascular endothelial growth factor mRNA expression in MCF-7 cells. Progesterone and progestins increased vascular endothelial growth factor mRNA expression in T-47D breast cancer cells, but $\delta 4$-tibolone was less effective than progestogens on this angiogenic gene expression in the $T$ $47 D$ cells. This differential effect might be related

Abbreviations: CEE, conjugated equine oestrogens; HRT, hormone replacement therapy; MPA, medroxyprogesterone acetate 


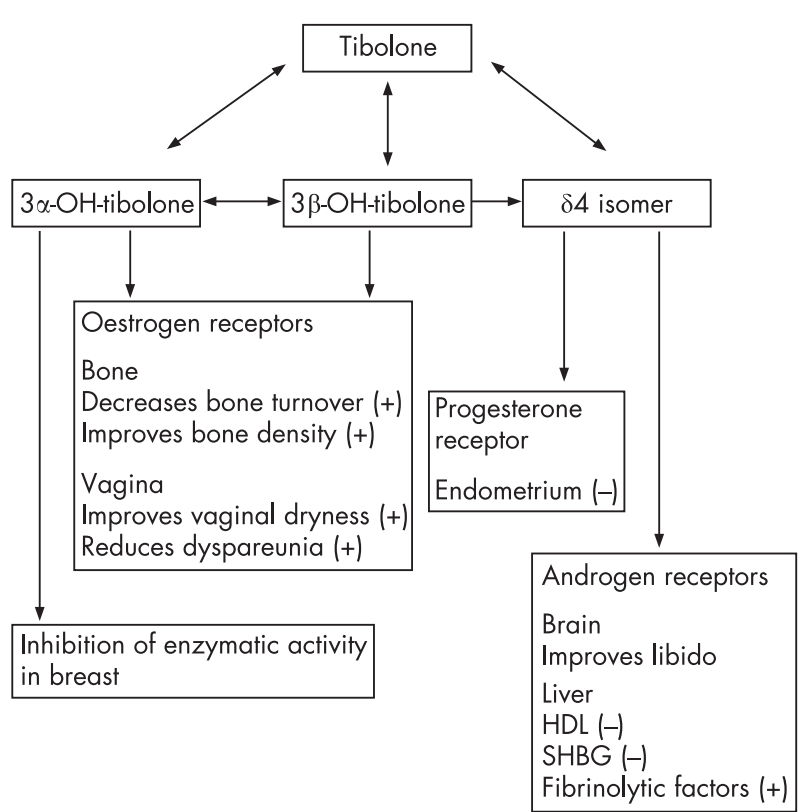

Figure 1 Tissue-specific effects of tibolone and its metabolites. +, stimulatory effects; - , suppressive effects; HDL, high-density lipoprotein; SHBG, sex hormone-binding globulin.

to breast cancer growth. ${ }^{11}$ Neither tibolone nor its metabolites act as substrates for aromatase; consequently, this pathway does not lead to any oestrogenic activity of tibolone. ${ }^{12}$

In contrast with these findings, it has been shown that tibolone increases aromatase activity, and in turn, local oestrogen concentration in the adipose tissue of the breast. ${ }^{13}$ In support of that finding, but in contrast with the results of all other studies, tibolone has been found to have growthpromoting effects on tumour cells in vitro. ${ }^{14}$ In summary, in vitro studies are inconclusive about the effects of tibolone on breast cells so far.

\section{ANIMAL STUDIES}

Animal studies have shown that tumour development and growth were successfully suppressed by giving tibolone in a dimethylbenzanthracene-induced tumour model in rats. ${ }^{15}$ The strong inhibitory effect of tibolone on tumour development

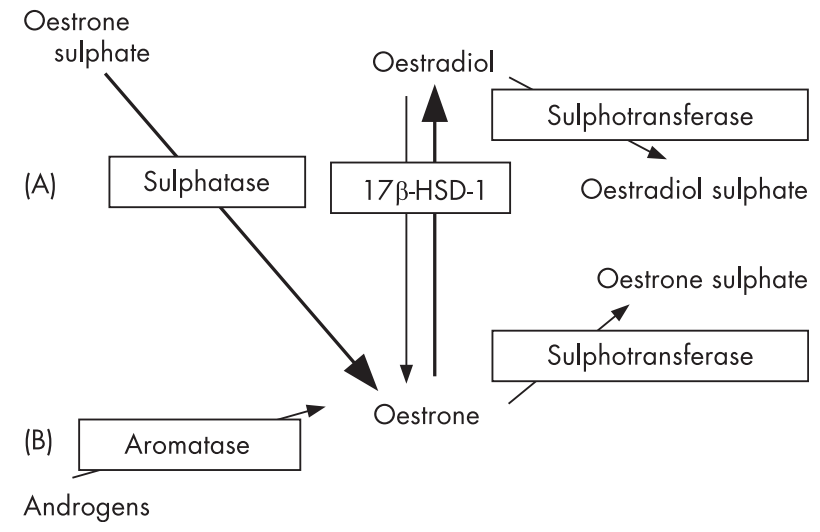

Figure 2 Enzymatic mechanisms involved in the formation and transformation of oestrogens in human breast cancer. The sulphatase pathway (A) is quantitatively 100-500 times more powerful and superior to the aromatase pathway (B). HSD, hydroxysteroid dehydrogenase. may be due to its androgenic and $\delta 4$ isomer activity. Recently, in an experimental model, it has been shown that tibolone as well as raloxifene and oestradiol did not promote breast cancer in rats treated with dimethylbenzanthracene. ${ }^{16}$

In studies with ovariectomised cynomolgus macaques, it has been reported that tibolone did not cause stimulation of the breast, as measured by an increase in breast epithelial tissue area and expression of the proliferation marker Ki-67 in breast epithelial cells. In addition, at higher doses, tibolone increased progesterone receptor expression in the breast tissue relative to controls, indicating a partial oestrogenagonist activity, but without induction of proliferation. ${ }^{17}$ Recently, Conner et $\mathrm{al}^{18}$ have reported that the expression of p53 and caspase- 3 in breast tissue was also markedly lower in tibolone-treated cynomolgus macaques than the other groups (conjugated equine oestrogens + medroxyprogesterone acetate (CEE+MPA) group, CEE only group and control group).

In conclusion, tibolone has a non-proliferative effect on breast tissue in ovariectomised cynomolgus macaques; however, uncertainty remains over its protective effect against breast cancer development in the dimethylbenzanthracene-induced tumour model in rats.

\section{RADIOLOGICAL AND CORRESPONDING HISTOPATHOLOGICAL STUDIES}

The data on the effects of tibolone on breast tissue were mostly extracted from radiological studies. An increase in mammographic density during HRT is an important finding. Increased mammographic density may obscure some lesions (masses and punctuate figures), causing an increase in the incidence of interval breast cancers and, therefore, it may decrease the sensitivity of mammography. In addition, doctors may recall patients with dense breast parenchyma more frequently, resulting in decreased specificity of mammography. ${ }^{1920}$ Finally, such factors could decrease patients' adherence to HRT by aggravating the fear of breast cancer or by reducing patients' confidence in this treatment, although, there might be a causal relationship between an extensive increase in mammographic density and histology related to breast cancer risk, particularly among women not receiving HRT. For example, it has been reported that the relative risk of ductal hyperplasia increased 13.9-fold and ductal atypical hyperplasia or carcinoma in situ increased 9.2-fold among women with an extensive increase in mammographic density. ${ }^{21}$ Even more importantly, there is some evidence that mammographic density increase during HRT is also associated with marked histopathological changes. ${ }^{22} 23$

In one of our previous studies, we observed that oestrogen and progestogen-based HRT caused an increase in mammographic density in approximately $11 \%$ of postmenopausal women. ${ }^{24}$ Although oestrogen-only regimens increase mammographic density less, the addition of a progestogen to oestrogen replacement therapy is most likely to cause an increase in mammographic density, and continuous combined HRT seems to be worse than cyclic combined HRT, ${ }^{24-28}$ whereas the non-oral route of oestrogen replacement therapy causes less increase in mammographic density than the oral route. ${ }^{29}$ A short-term suspension of HRT is known to reverse the increase in mammographic density. ${ }^{30}$ Therefore, if mammographic density increases in women on combined oestrogen-progestrogen preparations, decreases the mammographic sensitivity and increases the incidence of interval breast cancer, an alternative may be to perform mammography after a 3-4-week suspension of HRT.

Tibolone is an alternative to combined oestrogen-progestogen-based HRT, which may cause less increase in mammographic density. We first observed that tibolone had a minimal effect on mammographic density in postmenopausal 
women in a prospective, observational study. ${ }^{31}$ Most studies have shown minimal or no increase in mammographic density in women receiving tibolone treatment when compared with those treated with combined oestrogen and progestrogen therapy ${ }^{21}$ 25-27 31-40 (table 1).

Most studies examining the effects of tibolone on mammographic density have been either retrospective or prospective observational studies. ${ }^{27} 283133$ 34 37-39 Five randomised controlled trials were conducted which, unfortunately, included a small sample size of participants treated with tibolone, and the follow-up duration was quite short-no more than 12 months. ${ }^{22} 32353640$ A few studies had $>150$ participants ${ }^{27}{ }^{36} 38$ and only one of them was a randomised controlled trial. ${ }^{36}$ Although there seems to be no relationship between the duration of tibolone use and changes in mammographic density, only a couple of studies have extended the follow-up duration of mammographic surveillance beyond 4 years. $^{28} 39$

Three studies ${ }^{27} 338$ compared the effect of tibolone on mammographic density with different types and regimens of combined oestrogen-progestogen preparations. Three studies, including ours, ${ }^{22} 28$ compared a certain type of oestrogen and progestogen, CEE and MPA, with tibolone. Although Lundstorm $e t a l^{36}$ compared tibolone with oestradiol and norethisterone acetate, Colacurci et al ${ }^{32}$ compared tibolone with transdermal oestradiol and nomegestrol. On the other hand, in a recent 1 -year prospective study, tibolone was compared with raloxifene, and a similar increase in mammographic density was found, with only a small minority of women in both groups $(11 \%$ for tibolone and $6 \%$ for raloxifene).$^{37}$ Thus, there is only one ultrasonographic study showing a decrease in cyst size in the breast tissue of women treated with tibolone. ${ }^{41}$

More importantly, some evidence shows that an increase in mammographic density is also associated with histopathological changes in women on HRT. Moreover, these histopathological changes are less proliferative in women treated with tibolone than in those treated with oestrogen-progestogen-based HRT. Valdiva et $a l^{22}$ have compared the changes in mammographic density and the expression of markers of proliferation (Ki-67) and apoptosis ( $\mathrm{Bcl} 2$ ) after l year of treatment with tibolone and continuous CEEs combined with MPA in a randomised, evaluator-blinded study. They found that a l-year treatment with tibolone induced a decrease in breast density, with a reduction in proliferation and a stimulation of apoptosis, whereas a 1-year treatment with CEE+MPA induced an increase in breast density, with stimulation of proliferation and inhibition of apoptosis.

In a small substudy, Conner et $a^{23}$ compared the percentage of Ki-67/MIB-1-positive cells at baseline and after treatment with $2 \mathrm{mg}$ oestradiol/1 mg norethisterone acetate $(\mathrm{n}=14)$, tibolone $(n=15)$ or placebo $(n=16)$. This subgroup of women belonged to a larger group of 166 women who had a mammographic follow-up to evaluate the effects of different HRT regimens on breast density. ${ }^{36}$ During continuous combined oestradiol and norethisterone acetate, the percentage of MIB-1-positive breast cells increased almost threefold after 6 months, whereas the effect of tibolone did not differ considerably from that of placebo. This proliferation was markedly greater with oestrogen replacement therapy than with either tibolone or placebo. These findings indicate that tibolone had favourable effects on breast tissue that were different from those of oestrogen-progestogen-based HRT. In addition to this, they also indicate a relationship between changes in mammographic density and breast histopathology.

We can conclude that radiological studies and corresponding histopathological studies show a relatively favourable effect of tibolone on breast parenchyma during short-term use.

\section{EPIDEMIOLOGICAL STUDIES}

According to the conclusion on the relationship between the risk of breast cancer and tibolone use in the Million Women Study in 2003, breast cancer incidence was found to be markedly increased in women treated with tibolone (risk ratio (RR) $1.45,95 \%$ confidence interval (CI) 1.25 to 1.68$).{ }^{42}$ In this study, the use of tibolone increased the risk of breast cancer more than the use of oestrogen only (RR 1.30, 95\% CI 1.21 to 1.40 ), but less than the use of combined oestrogenprogestogen therapy (RR 2.00, 95\% CI 1.88 to 2.12 ).

There are some important limitations in the tibolone arm of the Million Women Study that are noteworthy. Firstly, breast cancer risk was reported to increase even in the first year of treatment with tibolone (RR 1.63, 95\% CI 1.04 to 2.56), which was much higher than that in women treated with oestrogen only or combined oestrogen-progestogenbased HRT. The average time that elapsed between inclusion in the study and the diagnosis of breast cancer was 1.2 years. Furthermore, the average time that elapsed between inclusion in the study and death from breast cancer was 1.7 years. These results lack biological plausibility.

Secondly, it is an observational study and therefore selection bias may have occurred. Indeed, the HRT regimen was changed in one third of women without giving any reason. In addition, the previous HRT and confounding risk factors, such as denser breast parenchyma, were not known in women treated with tibolone. For these reasons, the increased risk of breast cancer in the tibolone group should be re-evaluated. Most of the HRT products were being prescribed by general practitioners in the UK. General practitioners seem to preferentially prescribe tibolone for women with an increased risk of breast and endometrial cancers, as compared with women being prescribed other combined oestrogen-progestogen products. ${ }^{43}$

In 2004, the Danish Nurse Cohort study reported that tibolone was associated with an increased risk of breast cancer. ${ }^{44}$ In this study, tibolone was defined as one of the traditional European HRT regimens. Several limitations were also notable in the Danish study. Although an increased breast cancer risk was observed in women treated with tibolone, this was based on five cases in 79 women. The risk of breast cancer increased in the first year of HRT, which again lacks biological plausibility. This observational study was based on questionnaires, and although the number of mailed questionnaire forms was 22178 , only half of them (10 874) were included in the final analysis, adding to the statistical weakness of the study. In this study, mammographic surveillance was also lacking. Finally, the follow-up period from baseline to breast cancer diagnosis was 3.36 years, which is a relatively short period for the genesis of breast cancer.

In contrast with these epidemiological reports, tibolone has been studied for other indications such as relief of hot flushes in women with breast cancer. Its safety and efficacy have been investigated in a recent randomised, double-blinded, placebo-controlled study, where tibolone has improved the climacteric symptoms in 70 postmenopausal women receiving tamoxifen after surgery for breast cancer ${ }^{45}$. Women were randomised to receive $20 \mathrm{mg}$ /day of oral tamoxifen with either $2.5 \mathrm{mg} /$ day oral tibolone or placebo for 12 months. The frequency and intensity of hot flushes and sweats were assessed using the Landgren scale. The frequency of both hot flushes and sweats in women given tibolone was reduced compared with an increase in women on placebo. At the end of the study, the frequency of hot flushes had decreased by $34.8 \%$ with tibolone and increased by $52.6 \%$ with placebo, 
Table 1 Summary of studies on mammographic density in women being treated with various hormone replacement therapy drugs and regimens

\begin{tabular}{|c|c|c|c|c|c|c|}
\hline Author & Centre & $\mathbf{n}$ & $\begin{array}{l}\text { Duration } \\
\text { (months) }\end{array}$ & Agent & Study design & Conclusions \\
\hline Erel et $a^{\beta 1}$ & Istanbul, Turkey & 75 & 12 & Tibolone & $\begin{array}{l}\text { Prospective, } \\
\text { observational }\end{array}$ & $\begin{array}{l}\text { Tibolone has caused a low incidence } \\
\text { of } 8 \% \text { change }\end{array}$ \\
\hline Colacurci et $a^{\beta 2}$ & Naples, Italy & 44 & 12 & $\begin{array}{l}\text { Transdermal E2+ } \\
\text { Nomegesterol (cyclic), } \\
\text { tibolone, control }\end{array}$ & $\mathrm{RCT}$ & $\begin{array}{l}\text { EPRT increases breast density; } \\
\text { tibolone does not affect } \\
\text { mammographic density }\end{array}$ \\
\hline Ozdemir et $a^{\beta 3}$ & Ankara, Turkey & $118+30$ & 17 & $\begin{array}{l}\text { EV+cyproterone acetate, } \\
\mathrm{CEO}+\mathrm{MPA} \text {, tibolone, } \\
\text { oestrogen alone }\end{array}$ & $\begin{array}{l}\text { Prospective, } \\
\text { observational }\end{array}$ & $\begin{array}{l}\text { Density changes are dependent on } \\
\text { the HRT regimen, formation of cysts } \\
\text { and solid lesions is not related to HRT }\end{array}$ \\
\hline Sendag et $a f^{7}$ & Izmir, Turkey & 216 & 20 & $\begin{array}{l}\text { Oestrogen alone (CEE, E2), } \\
\text { oestrogen in cyclic or } \\
\text { continuous combination of } \\
\text { progestin (CEE+MPA, } \\
\text { E2+NETA), tibolone }\end{array}$ & $\begin{array}{l}\text { Prospective, } \\
\text { observational }\end{array}$ & $\begin{array}{l}\text { Continuous combined HRT had the } \\
\text { most prominent effects on density }\end{array}$ \\
\hline Erel et $a{ }^{p 8}$ & Istanbul, Turkey & 95 & 48 & $\begin{array}{l}C E E+M P A \text {, continuous and } \\
\text { sequential, tibolone }\end{array}$ & Retrospective & $\begin{array}{l}\text { Different HRT regimens have different } \\
\text { effects on density, continuous } \\
\text { combined regimens are more } \\
\text { effective than other forms. }\end{array}$ \\
\hline Colacurci et $a \beta^{\beta 4}$ & Naples, Italy & 121 & 12 & $\begin{array}{l}\text { Transdermal E2+Nomegestrol } \\
\text { (cyclic, continuous), tibolone, } \\
\text { transdermal E2 only, control }\end{array}$ & $\begin{array}{l}\text { Prospective, } \\
\text { observational }\end{array}$ & $\begin{array}{l}\text { Continuous EPRT clearly increases } \\
\text { breast density, tibolone does not } \\
\text { affect mammographic density }\end{array}$ \\
\hline Egarter et $a f^{\beta 5}$ & Vienna, Austria & 20 & 6 & Tibolone $v$ placebo & $\mathrm{RCT}$ & Tibolone decreases breast density \\
\hline Lundstrom et $a^{\beta 6}$ & $\begin{array}{l}\text { Stockholm and } \\
\text { Vasteras Sweden, } \\
\text { Oss, The } \\
\text { Netherlands }\end{array}$ & 166 & 6 & Tibolone, E2/NETA, placebo & $\mathrm{RCT}$ & $\begin{array}{l}\text { More evident density increase in } \\
\text { women treated with continuous } \\
\text { combined regimens than in those } \\
\text { treated with tibolone or placebo }\end{array}$ \\
\hline Christodoulakos $^{37}$ & Athens, Greece & 131 & 12 & Raloxifene, tibolone, control & $\begin{array}{l}\text { Prospective, } \\
\text { observational }\end{array}$ & $\begin{array}{l}10 \% \text { in the tibolone, } 6 \% \text { in the } \\
\text { raloxifene groups but none in the } \\
\text { control group had increased density; } \\
11 \% \text { in the tibolone, } 19 \% \text { in the } \\
\text { raloxifene and } 26 \% \text { in the control } \\
\text { groups had decreased density (non- } \\
\text { significant findings) }\end{array}$ \\
\hline Bulbul et $a^{\beta 8}$ & Istanbul, Turkey & 182 & 12 & $\begin{array}{l}\text { Oestrogen alone (CEE, E2), } \\
\text { oestrogen/progestogen } \\
\text { sequential or continuous } \\
\text { (CEE+MPA, E2+NETA) }\end{array}$ & $\begin{array}{l}\text { Prospective, } \\
\text { observational }\end{array}$ & $\begin{array}{l}\text { Most evident increase in women on } \\
\text { continuous combined therapy; least } \\
\text { in those on tibolone; increased breast } \\
\text { density associated with breast } \\
\text { tenderness and more common in } \\
\text { obese women }\end{array}$ \\
\hline Valdiva et a ${ }^{22}$ & Santiago, Chile & 37 & 12 & $\begin{array}{l}\text { Tibolone } v \text { CEE }+ \text { MPA } \\
\text { continuous }\end{array}$ & $\mathrm{RCT}$ & $\begin{array}{l}\text { Tibolone induces a decrease in breast } \\
\text { density }\end{array}$ \\
\hline Bruce et $a l^{\beta 9}$ & London, UK & 113 & 120 & Tibolone & $\begin{array}{l}\text { Prospective, } \\
\text { observational }\end{array}$ & $\begin{array}{l}\text { Tibolone did not affect breast density } \\
\text { adversely in over } 10 \text { years }\end{array}$ \\
\hline Marchesoni et $a f^{40}$ & Udine, Italy & 103 & 12 & $\begin{array}{l}\text { Tibolone, CEE }+ \text { MPA } \\
\text { continuous, placebo }\end{array}$ & $\mathrm{RCT}$ & $\begin{array}{l}\text { Continuous CEE }+ \text { MPA increased } \\
\text { breast density more evidently that } \\
\text { tibolone did }\end{array}$ \\
\hline
\end{tabular}

CEE, conjugated equine oestrogens; E2, oestradiol; EV, oestradiol valerate; EPRT, oestrogen-progesterone replacement therapy; HRT, hormone replacement therapy; MPA, medroxyprogesterone acetate; NETA, norethindrone acetate; RCT, randomised controlled trial.

compared with baseline. The primary end point of the study was the climacteric symptoms, and although the follow-up duration of 12 months was a relatively short period, a recurrence of breast cancer or a new cancer focus was not detected in this group of patients.

\section{CONCLUSIONS}

In vitro studies have reported conflicting results on the effects of tibolone on breast cells. On the other hand, although epidemiological studies have shown an increase in the risk of breast cancer among women treated with tibolone, accumulated data obtained from various radiological studies are promising. However, the issue of safety of tibolone in breast tissue needs further study, especially through welldesigned, large-scale, randomised controlled trials.

Although there is no randomised controlled trial, such as the Women' Health Initiative study ${ }^{46}$ investigating the effects of tibolone on breast cancer risk, a multinational, doubleblind, placebo-controlled study is currently under way (Livial Intervention following Breast cancer; Efficacy, Recurrence And Tolerability Endpoints) to further investigate the effects of tibolone in women surgically treated for breast cancer in the past 5 years. A total of 2600 women will be recruited and treated for 4 years. This study aims to investigate the 
recurrence of breast cancer, as well as the overall survival rates, climacteric symptoms, bone mineral density values and the incidence of thrombosis.

\section{Authors' affiliations}

C T Erel, L M Senturk, S Kaleli, Department of Obstetrics and Gynecology, Division of Reproductive Endocrinology, Cerrahpasa School of Medicine, Istanbul University, Istanbul, Turkey

Competing interests: None declared.

\section{REFERENCES}

1 Palacios S. Tibolone. What does tissue specific activity mean? Maturitas 2001;37:159-65

2 Kloosterboer HJ. Tibolone: a steroid with a tissue-specific mode of action. Steroid Biochem Mol Biol 2001;76:231-8.

3 Tang BLK, Markiewicz HJ, Gurpide E. Human endometrial $3 \alpha$-hydroxysteroid dehydrogenase/isomerase can locally reduce intrinsic estrogenic/ progestagenic activity ratios of a steroidal drug (OrgOD14). J Steroid Biochem Mol Biol 1993:45:345-51.

4 Markiewicz L, Gurpide E. Estrogenic and progestagenic activities coexisting in steroidal drugs: quantitative evaluation by in vitro bioassays with human cells. J Steroid Biochem Mol Biol 1994:48:89-94.

5 Modelska K, Cummings S. Tibolone for postmenopausal women: systematic review of randomized trial. J Clin Endocrinol Metab 2002;87:16-23.

6 Pasqualini JR, Chetrite GS. Recent insight on the control of enzymes involved in estrogen formation and transformation in human breast cancer. J Steroid Biochem Mol Biol 2005;93:221-36.

7 Cherite G, Kloosterboer HJ, Pasqualini JR. Effect of tibolone (Org OD14) and its metabolites on estrone sulphatase activity in MCF-7 and T-47D mammary cancer cells. Anticancer Res 1997;17:135-40.

8 Pasqualini JR, Kloosterboer HJ. Estrone sulfatase and 17 $\beta$-hydroxysteroid dehydrogenase activities in human breast cancer. Inhibitory effect by tibolone and its metabolites. Acta Obstet Gynaecol Scand 1997;76(Suppl 167):35.

9 Chetrite GS, Kloosterboer HJ, Philippe JC, et al. Effect of Org OD14 (Livial ${ }^{\circledR}$ ) and its metabolites on human estrogen sulphotransferase activity in the hormone-dependent MCF-7 and T- 47D, and the hormone independent MDAMB-231, breast cancer cells lines. Anticancer Res 1999:19:269-76.

10 Gompel A, Chaouat $M$, Jacob D, et al. In vitro studies of tibolone in breast cells. Fertil Steril 2002;78:351-9.

11 Mirkin S, Wong BC, Archer DF. Effect of 17 $\beta$-estradiol, progesterone, synthetic progestins, tibolone, and tibolone metabolites on vascula endothelial growth factor mRNA in breast cancer cells. Fertil Steril 2005;84:485-91.

12 Gooyer de ME, Oppers-Tiemissen HM, Leysen D, et al. Tibolone is not converted by human aromatase to $7 \alpha$-methyl-17 $\alpha$-ethynylestradiol $(7 \alpha-M E E)$ : analyses with sensitive bioassays for estrogens and androgens and with LCMS/MS. Steroids 2003;68:235-43.

13 van de Ven J, Donker G, Sprong M, et al. Effect of tibolone (Org OD14) and its metabolites on aromatase and estrone sulfatase activity in human breast adipose stromal cells and in MCF-7 and T47D breast cancer cells. J Steroid Biochem Mol Biol 2002;81:237-47.

14 Lippert C, Seeger H, Wallwiener D, et al. Tibolone versus 17beta-estradiol/ norethisterone: effects on the proliferation of human breast cancer cells. Eur J Gynaecol Oncol 2002;23:127-30.

15 Kloosterboer HJ, Schoonen WG, Deckers GH, et al. Effects of progestrogens and Org ODI 4 in in vitro and in vivo tumor models. J Steroid Biochem Mol Biol 1994;49:311-18.

16 Callejo J, Cano A, Medina M, et al. Hormonal environment in the induction of breast cancer in castrated rats using dimethylbenzanthracene: influence of the presence or absence of ovarian activity and of treatment with estradiol, presence or absence of ovarian activity and of treatment
tibolone, and raloxifene. Menopause 2005;12:601-8.

17 Cline JM, Register TC, Clarkson TB. Effects of tibolone and hormone replacement therapy on the breast of cynomolgus monkeys. Menopause 2002;9:422-9

18 Conner P, Register PC, Skoog L, et al. Expression of p53 and markers for apoptosis in breast tissue during long-term hormone therapy in cynomolgus monkeys. Am J Obstet Gynecol 2005;193:58-63.

19 Litherland JC, Evans AJ, Wilson AR. The effect of hormone replacement therapy on recall rate in the National Health Service Breast Screening Programme. Clin Radiol 1997;52:276-9.

20 Litherland JC, Stallard S, Hole D, et al. The effect of hormone replacement therapy on the sensitivity of screening mammograms. Clin Radiol 1999:54:285-8.
21 Boyd NF, Jensen HM, Cooke G, et al. Mammographic densities and the prevalence and incidence of histological types of benign breast disease. Eur J Cancer Prev 2000;9:15-24.

22 Valdivia I, Campodónico I, Tapia A, et al. Effect of tibolone and continuous combined hormone replacement therapy on mammographic breast density and breast histochemical markers in postmenopausal women. Fertil Steril 2004;81:617-23.

23 Conner P, Christow A, Kersemaekers W. A comparative study on breast cell proliferation during HRT effects of tibolone and continuous combined estrogen progestogen treatment. Climacteric 2004;7:50-8.

24 Erel CT, Seyisoğlu H, Șentürk ML, et al. Mammographic changes in women on hormonal replacement therapy. Maturitas 1996;25:51-7.

25 Greendale GA, Reboussin BA, Sie A, et al. Effects of estrogen and estrogenprogestin on mammographic parenchymal density. Postmenopausal Estrogen/Progestin Interventions (PEPI) Investigators. Ann Intern Med 1999:130:262-9.

26 Lundstrom E, Wilczek B, vonPalffy Z, et al. Mammographic breast density during hormone replacement therapy: differences according to treatment. Am J Obstet Gynecol 1999;181:348-52.

27 Sendag F, Cosan Terek M, Ozsener S, et al. Mammographic density changes during different postmenopausal hormone replacement therapies. Fertil Steril 2001;76:445-50.

28 Erel CT, Esen G, Seyisoglu H, et al. Mammographic density increase in women receiving different hormone replacement regimens. Maturitas 2001;40:151-7.

29 Lundstrom E, Wilczek B, von Palffy Z, et al. Mammographic breast density during hormone replacement therapy: efects of continuous combination, unopposed transdermal and low-potency estrogen regimens. Climacteric 2001;4:42-8.

30 Colacurci N, Fornaro F, DeFranciscis P, et al. Effects of a short-term suspension of hormone replacement therapy on mammographic density. Fertil Steril $2001 ; 76: 451-5$.

31 Erel CT, Elter K, Akman C, et al. Mammographic changes in women receiving tibolone therapy. Fertil Steril 1998;69:870-5.

32 Colacurci N, Mele D, De Franciscis $\mathrm{P}$, et al. Effects of tibolone on the breast. Eur J Obstet Gynecol Reprod Biol 1998;80:235-8.

33 Ozdemir A, Konus O, Nas T, et al. Mammographic and ultrasonographic study of changes in the breast related to HRT. Int J Gynaecol Obstet 1999;67:23-32.

34 Colacurci N, Fornaro F, De Franciscis P, et al. Effects of different types of hormone replacement therapy on mammographic density. Maturitas 2001;40:159-64.

35 Egarter C, Eppel W, Vogel S, et al. A pilot study of hormone replacement therapy with tibolone in women with mastopathic breasts. Maturitas 2001;40:165-71

36 Lundstrom E, Christow A, Kersemaekers W, et al. Effects of tibolone and continuous combined hormone replacement therapy on mammographic breast density. Am J Obstet Gynecol 2002;186:717-22.

37 Christodoulakos GE, Lambrinoudaki IV, Vourtsi AD, et al. Mammographic changes associated with raloxifene and tibolone therapy in postmenopausal women: a prospective study. Menopause 2002;9:110-16.

38 Bulbul NH, Ozden S, Dayicioglu V. Effects of hormone replacement therapy on mammographic findings. Arch Gynecol Obstet 2003;268:5-8.

39 Bruce D, Robinson J, McWilliams S, et al. Long-term effects of tibolone on mammographic density. Fertil Steril 2004;82:1343-7.

40 Marchesoni D, Driul L, lanni A, et al. Postmenopausal hormone therapy and mammographic breast density. Maturitas 2006;53:59-64.

41 Yenen MC, Dede M, Goktolga U, et al. Hormone replacement therapy in postmenopausal women with benign fibrocystic mastopathy. Climacteric 2003;6: 146-50.

42 Million Women Study Collaborators. Breast cancer and hormonereplacement therapy in the Million Women Study. Lancet 2003;362:419-27.

43 Wierik EJ, Hendricks PT, Boerstoel-Streefland M. Clinical background of women prescribed tibolone or combined estrogen + progestogen therapies: a UK MediPlus study. Climacteric 2004;7:197-209.

44 Stahlberg C, Pedersen AT, Lynge E, et al. Increased risk of breast cancer following different regimens of hormone replacement therapy frequently used in Europe. Int J Cancer 2004; 109:721-7.

45 Kroiss R, Fentiman IS, Helmond FA, et al. The effect of tibolone in postmenopausal women receiving tamoxifen after surgery for breast cancer: a randomised, double-blind, placebo-controlled trial. BJOG 2005; 112:228-33.

46 Writing Group for the WHI Investigators. Risks and benefits of estrogen plus progestin in healthy postmenopausal women: principal results from the Women's Health Initiative Randomized Controlled Trial. JAMA 2002;288:321-33. 


\section{Clinical Evidence-Call for contributors}

Clinical Evidence is a regularly updated evidence-based journal available worldwide both as a paper version and on the internet. Clinical Evidence needs to recruit a number of new contributors. Contributors are healthcare professionals or epidemiologists with experience in evidence-based medicine and the ability to write in a concise and structured way.

Areas for which we are currently seeking contributors:

- Pregnancy and childbirth

- Endocrine disorders

- Palliative care

- Tropical diseases

We are also looking for contributors for existing topics. For full details on what these topics are please visit www.clinicalevidence.com/ceweb/contribute/index.jsp

However, we are always looking for others, so do not let this list discourage you.

Being a contributor involves:

- Selecting from a validated, screened search (performed by in-house Information Specialists) epidemiologically sound studies for inclusion.

- Documenting your decisions about which studies to include on an inclusion and exclusion form, which we keep on file.

- Writing the text to a highly structured template (about 1500-3000 words), using evidence from the final studies chosen, within 8-10 weeks of receiving the literature search.

- Working with Clinical Evidence editors to ensure that the final text meets epidemiological and style standards.

- Updating the text every 12 months using any new, sound evidence that becomes available. The Clinical Evidence in-house team will conduct the searches for contributors; your task is simply to filter out high quality studies and incorporate them in the existing text.

If you would like to become a contributor for Clinical Evidence or require more information about what this involves please send your contact details and a copy of your CV, clearly stating the clinical area you are interested in, to CECommissioning@bmigroup.com.

\section{Call for peer reviewers}

Clinical Evidence also needs to recruit a number of new peer reviewers specifically with an interest in the clinical areas stated above, and also others related to general practice. Peer reviewers are healthcare professionals or epidemiologists with experience in evidence-based medicine. As a peer reviewer you would be asked for your views on the clinical relevance, validity, and accessibility of specific topics within the journal, and their usefulness to the intended audience (international generalists and healthcare professionals, possibly with limited statistical knowledge). Topics are usually 1500-3000 words in length and we would ask you to review between 2-5 topics per year. The peer review process takes place throughout the year, and out turnaround time for each review is ideally 10-14 days.

If you are interested in becoming a peer reviewer for Clinical Evidence, please complete the peer review questionnaire at www.clinicalevidence.com/ceweb/contribute/peerreviewer.jsp 